\title{
Increase of the Frame Support Yield Load by Full Filling of Behind-Anchoring Space with Grout Material
}

\author{
Viktor Tatsienko \\ Mining Institute \\ T.F. Gorbachev Kuzbass State \\ Technical University \\ Kemerovo, Russian Federation \\ ipeb@kuzstu.ru
}

\author{
Alexander Liskovets \\ Mining Institute \\ T.F. Gorbachev Kuzbass State \\ Technical University \\ Kemerovo, Russian Federation \\ promsnab_kmr@mail.ru
}

\author{
Maxim Sablin \\ A.D.Ruban Underground Mining Office \\ OJSC «SUEK-Kuzbass» \\ Leninsk-Kuznetsky, Russian Federation \\ sablinmv@suek.ru
}

\begin{abstract}
The article presents brief description and results of laboratory and in-situ tests of frame support with backfilling of behind-anchoring space with grout. Characteristics of mining and geological conditions on the site of inclined conveyor shaft of Sychevskiy-I mine-section, A.D. Ruban Mine (JSC SUEK-Kuzbass) has been given. Grouting quality has been tested according to described technology, strength characteristics of cement and degree of grout mix influence on the surrounding rock mass has been determined. It is figured out that reinforced canvas use as a between-frame overlap increases cement strength. Some recommendations regarding the use of reinforced canvas as a grouting material have been formulated.
\end{abstract}

Keywords-frame roof support, grouting, behind-anchoring space, rock grouting

\section{INTRODUCTION}

In Kuzbass skin grouting is widespread during mining operations in difficult geological conditions (transition of water-bearing formation, unstable rocks, zones of violations influence, etc.). Skin grouting technologies and rock mass injection hardening [1-8] in combination with traditional types of supports were used in many mines of Kuznetsk Basin. Main reason for constraining application of injection hardening as a method to improve stability of mine workings [9-15] are the lack of geo-mechanical substantiation for excavation support considering grout mix water loss under pressure, the lack of structures and technology for construction of insulating shells around workings, as well as workable grouting complexes for injection operations Since most geological conditions of Kuzbass are complicated, the tasks outlined in the article are relevant.

\section{MATERIALS AND METHODS}

Within the technology study for enhancement of frame roof support bearing capacity by complete backfilling of behind-anchoring space, laboratory and bench tests of elements of mine workings support and in-situ experimental study of system state 'support - grout layer - rock mass' have been carried out in inclined conveyor shaft of Sychevskiy-I mine-section, A.D. Ruban Mine, JSC SUEK-Kuzbass. The object of the study was grouting support (grout layer, rock mass around grout layer). Structural diagram of the support under study is shown on Fig. 1.
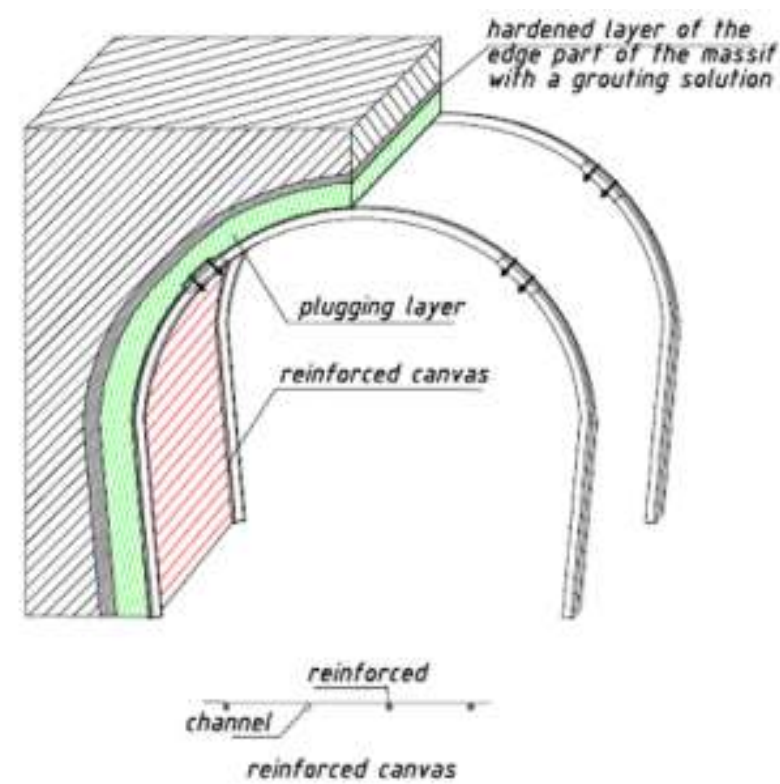

Fig. 1. Structural diagram of the support under study.

Frame grout roof support (Fig. 1) of mine working consists of metal frame support, grout layer, reinforced canvas as a between-frame overlap with internal transverse channels and reinforced steel rods inside them.

Frame grout roof support of mine working is built in the following way: after installation of metal support frames of special section, above they lay out reinforced rolled canvas made of filtering liquid material. In space between reinforced canvas and mine working wall grout mix is pumped. Excessive water (liquid phase), giving fluidity to the injected hardening material is filtered out through reinforced rolled canvas, after that cement slurry hardens forming a layer of artificial stone.

Thus, reinforced rods in special channels inside of rolled canvas serve as external reinforcement.

\section{TESTING OF SAMPLES OF MINE WORKINGS SUPPORT ELEMENTS}

Purpose of the tests was to compare parameters of the roof support elements. Samples of grouting support, concrete 
and metal grid-type tightening were prepared. For testing, samples of grouting roof supports were used of different thicknesses and age ( 1 day, 7 days and 28 days), $1200 \mathrm{~mm}$ length, $300 \mathrm{~mm}$ width, made of cement slurry used for

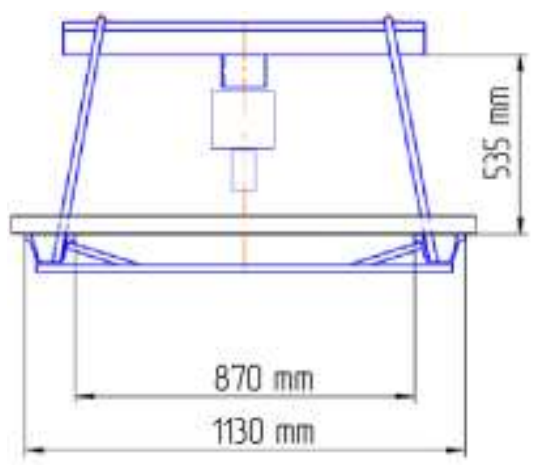

Fig. 2. Structural diagram of the support under study.

grouting operations on the interval of the conveyor shaft, Sychevkiy-I mine section, and reinforced canvas. Tests were performed in accordance with GOST 10180-2012 "Concretes. Methods of Strength Evaluation on Cube Test Specimens". Samples were loaded by piston of $0.001765 \mathrm{~m} 2$ contact area. Design of the test bench is shown on Fig. 2.

The test results of the roof support elements (samples of grouting support and reinforced tightening) are in Table I.

The test results of the roof support elements (reinforced canvas and grid-type tightening) are in Table II.

TABLE I. THE TEST RESULTS OF THE ROOF SUPPORT ELEMENTS

\begin{tabular}{|c|c|c|c|c|}
\hline Age & $\begin{array}{l}\text { Sample } \\
\text { name }\end{array}$ & $\begin{array}{l}\text { Maximum } \\
\text { load, kg }\end{array}$ & $\begin{array}{l}\text { Maximum } \\
\text { pressure, } \\
\text { bar }\end{array}$ & $\begin{array}{l}\text { Displace- } \\
\text { ment, mm }\end{array}$ \\
\hline \multirow{4}{*}{$\begin{array}{l}1 \\
\text { day }\end{array}$} & $\begin{array}{l}\text { Element TK, } \\
50 \mathrm{~mm}\end{array}$ & 157 & 7 & 2 \\
\hline & $\begin{array}{l}\text { Element TK, } \\
100 \mathrm{~mm}\end{array}$ & 560 & 25 & 2 \\
\hline & $\begin{array}{l}\text { Element TK, } \\
150 \mathrm{~mm}\end{array}$ & 1360 & 60 & 2 \\
\hline & $\begin{array}{l}\text { Element TK, } \\
200 \mathrm{~mm}\end{array}$ & 2464 & 110 & 5 \\
\hline \multirow{4}{*}{$\begin{array}{l}7 \\
\text { days }\end{array}$} & $\begin{array}{l}\text { Element TK, } \\
50 \mathrm{~mm}\end{array}$ & 269 & 12 & 2 \\
\hline & $\begin{array}{l}\text { Element TK, } \\
100 \mathrm{~mm}\end{array}$ & 672 & 30 & 2 \\
\hline & $\begin{array}{l}\text { Element TK, } \\
150 \mathrm{~mm}\end{array}$ & 1792 & 80 & 2 \\
\hline & $\begin{array}{l}\text { Element TK, } \\
200 \mathrm{~mm}\end{array}$ & 3584 & 160 & 6 \\
\hline \multirow{4}{*}{$\begin{array}{l}28 \\
\text { days }\end{array}$} & $\begin{array}{l}\text { Element TK, } \\
50 \mathrm{~mm}\end{array}$ & 448 & 20 & 2 \\
\hline & $\begin{array}{l}\text { Element TK, } \\
100 \mathrm{~mm}\end{array}$ & 1008 & 45 & 2 \\
\hline & $\begin{array}{l}\text { Element TK, } \\
150 \mathrm{~mm}\end{array}$ & 2240 & 100 & 2 \\
\hline & $\begin{array}{l}\text { Element TK } \\
200 \mathrm{~mm}\end{array}$ & 3478 & 155 & 5 \\
\hline \multirow{3}{*}{-} & $\begin{array}{l}\text { Reinforced } \\
\text { tightening, } \\
\text { sample \#1 }\end{array}$ & 784 & 35 & 19 \\
\hline & $\begin{array}{l}\text { Reinforced } \\
\text { tightening, } \\
\text { sample \#2 }\end{array}$ & 673 & 30 & 23 \\
\hline & $\begin{array}{l}\text { Reinforced } \\
\text { tightening, } \\
\text { sample \#3 }\end{array}$ & 112 & 5 & 7 \\
\hline
\end{tabular}

TABLE II. THE TEST RESULTS OF THE ROOF SUPPORT ELEMENTS

\begin{tabular}{|l|l|l|l|}
\hline Sample name & $\begin{array}{l}\text { Maximum } \\
\text { load, kg }\end{array}$ & $\begin{array}{l}\text { Maximum } \\
\text { pressure, bar }\end{array}$ & $\begin{array}{l}\text { Displacement, } \\
\text { mm }\end{array}$ \\
\hline Reinforced canvas & 898 & 40 & 87 \\
\hline Reinforced canvas & 785 & 35 & 100 \\
\hline $\begin{array}{l}\text { Grid-type } \\
\text { tightening }\end{array}$ & 898 & 40 & 97 \\
\hline $\begin{array}{l}\text { Grid-type } \\
\text { tightening }\end{array}$ & 561 & 25 & 100 \\
\hline
\end{tabular}

\section{RESULTS AND DISCUSSION}

During laboratory tests of the roof support elements it was figured out:

- yield load of the roof support elements made of grout mix and reinforced canvas is comparable to concrete tightening;

- resistance values of reinforced canvas in terms of external loads meet values of grid-type tightening.

Furthermore, the study revealed that use of reinforced canvas as a between-frame overlap increases cement strength by $30 \%$ due to the timely excess fluid (water) removal from grout mix through canvas, so there is an optimization of matching of solid and liquid phases of the mix that accelerates concrete setting time and improves its strength parameters.

Table III presents the results of simple compression tests on cement samples made using a standard formwork (wooden half-beam, reinforced concrete tightening) (sample \#1) and reinforced canvas as formwork (sample \#2).

TABLE III. THE TEST RESULTS OF THE SIMPLE COMPRESSION

\begin{tabular}{|c|c|c|c|c|c|c|}
\hline 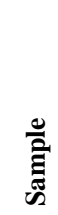 & $\overrightarrow{\tilde{\theta}}$ & 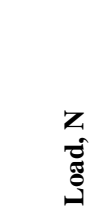 & 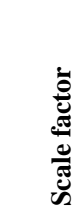 & 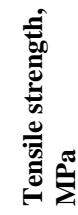 & 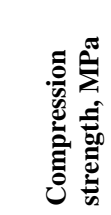 & 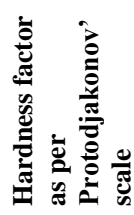 \\
\hline \multirow{5}{*}{1} & 1 & 97.80 & 0.97 & 0.54 & 8.59 & 0.9 \\
\hline & 2 & 440.10 & 1.08 & 1.73 & 27.60 & 2.8 \\
\hline & 3 & 154.85 & 0.87 & 1.16 & 18.56 & 1.9 \\
\hline & 4 & 40.75 & 0.98 & 0.22 & 3.48 & 0.3 \\
\hline & 5 & 130.40 & 0.91 & 0.87 & 13.88 & 1.4 \\
\hline & & & & & average: & 1.4 \\
\hline \multirow{5}{*}{2} & 6 & 203.75 & 0.91 & 1.36 & 21.69 & 2.2 \\
\hline & 7 & 130.40 & 0.96 & 0.75 & 11.96 & 1.2 \\
\hline & 8 & 309.70 & 0.91 & 2.02 & 32.37 & 3.2 \\
\hline & 9 & 195.60 & 0.96 & 1.12 & 17.94 & 1.8 \\
\hline & 10 & 187.45 & 0.88 & 1.37 & 22.00 & 2.2 \\
\hline & & & & & average: & 2.1 \\
\hline
\end{tabular}


Selection of location for field tests, mining and geological conditions:

Technology test to increase yield load frame support by complete filling of behind-anchoring space with grout was carried out in the inclined conveyor shaft, Sychevskiy-I mine-section, A.D. Ruban Mine JSC SUEK-Kuzbass.

The inclined conveyor shaft was previously worked on the formation Sychevskiy-I by shearer method and then anchored. The cross-section is up to $20 \mathrm{~m} 2$. Later, strengthening operations were performed by metal threetiered arch support A-16-27 with $1 \mathrm{~m}$ installation step and retightened by reinforced concrete tightening. With regard to presence of significant uncushioned cavities behindanchoring space and lack of direct contact of supporting frames with wall rocks, arch support had exclusively protecting functions. In view of the long service life, high coal and wall rocks fracturing, and tendency of Sychevskiy-I formation to spontaneous combustion, as well as successful completion of the skin grouting technology tests using reinforced canvas as a between-frame overlap and flexible formwork, a decision was taken to carry out skin grouting operations in the inclined conveyor shaft Sychevskiy-I as per the described technology hereinabove.

Mining operations in mine Sychevskiy-I revealed rock faults from the roof direction having the character of erosion. In these sections production capacity can be reduced to $2.7 \mathrm{~m}$. Seam hypsometry is complicated. There is a significant plication dislocation, and presence of anticlinal folds and downfolds with amplitudes of $4 \div 7 \mathrm{~m}$. Folds are relatively shallow dome-shaped and have elongated comb-like appearance. The most intense fracturing of coal and wall rocks associated with the places with maximum plication dislocation. The same fracture associated with seam fault line the disjunctive displacement amplitude of $0.10 \div 0.15 \mathrm{~m}$. Furthermore, the high natural coal and wall rock fracture additionally aggravated by mass explosions during production operations at Mokhovskiy site.

The main seam roof presented by coarse-grained siltstone of medium resistance, fractured with hardness factor $4 \div 6$ as per prof. Protodjakonov's scale. The average capacity of the main roof is $14 \mathrm{~m}$.

The direct roof is presented by medium-resistant clay fine-grained siltstone with hardness factor of $3 \div 4$ as per prof. Protodjakonov's scale. The capacity of the direct roof is $4 \div 8$ $\mathrm{m}$. In some areas there is the occurrence of fine-grained sandstone directly above the false seam roof or even absence of siltstone in the direct roof.

False seam roof presented by clayey fine-grained siltstone, very unstable, prone to disintegration, of $0.4 \div 0.6 \mathrm{~m}$ capacity, with hardness factor of 3 as per prof. Protodjakonov's scale. The direct seam soil presented by fine-grained siltstone of $8 \div 13 \mathrm{~m}$ capacity, slightly fractured, prone to erosion, with hardness factor of $3 \div 4$. All wall rocks are silicosis hazardous.

\section{The main test objectives in mine conditions:}

To confirm efficiency of the skin grouting technology by using reinforced canvas as a between-frame overlap and flexible formwork.
To verify grouting quality as per the noted technology, cement strength characteristics and influence degree of cement slurry on the shaft wall rock.

To determine possibility of reinforced canvas use as a tightening of the between-frame space.

\section{Organization of works to run tests:}

The pump unit of PBN-15KPC type was installed $50 \mathrm{~m}$ from the work site. On the part of the shaft of up to $5 \mathrm{~m}$ length removal of the reinforced concrete tightening. In this area between-frame space tightened by reinforced canvas. The time spent on retightening of one frame did not exceed 15 minutes.

To avoid grout mix leakage through side clearance two barrier hoses were installed at the first approach - at the beginning of the experimental section and at the end. After filling barrier sleeves by grout mix the skin grouting was carried out.

Injection duration is defined by:

- $\quad$ pump production capacity;

- $\quad$ void volume in behind anchoring space;

- level of work organization of the pump unit operators.

The grout mix feed rate was 3.0-4.8 m3/hr. In some shifts under proper organization of work it was possible to pump over $10 \mathrm{t}$ of cement slurry, as a result over $14 \mathrm{~m} 3$ of behind anchoring space were filled.

Upon completion of skin grouting and concrete strength development, physical and mechanical parameters of the grouting mix (stone) and the containing flank rocks in the inclined conveyor shaft of the Sychevskiy mine-section were evaluated, the results are in Table IV.

During laboratory core tests it figured out that:

- there is an inverse relation between cement slurry depth of penetration and cement hardness factor;

- the size of the core fragments varies from 40 to $120 \mathrm{~mm}$, the fracture degree is estimated as average;

- in the process of empty space filling between arched support and mine flank, penetration depth of the cement slurry was $50 \mathrm{~mm}$ (Fig. 3).

TABLE IV. THE TEST RESULTS OF THE SIMPLE COMPRESSION

\begin{tabular}{|c|c|c|c|c|c|c|}
\hline \multirow[b]{2}{*}{$\begin{array}{c}\text { Core } \\
\text { structure }\end{array}$} & \multicolumn{6}{|c|}{$\begin{array}{l}\text { Lab test on simple core compression, well \#1 in the } \\
\text { inclined conveyor shaft Sychevskiy, SP } 6+15.4 \mathrm{~m}\end{array}$} \\
\hline & 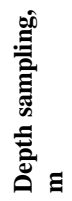 & 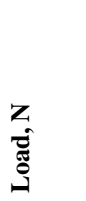 & 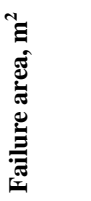 & 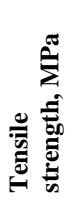 & 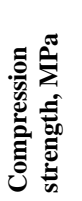 & 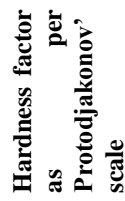 \\
\hline $\begin{array}{l}\text { Cement } \\
\text { slurry }\end{array}$ & 0.10 & 277.1 & 0.0008 & 2.17 & 26.03 & 2.6 \\
\hline $\begin{array}{l}\text { Cement } \\
\text { slurry }\end{array}$ & 0.32 & 211.9 & 0.0010 & 1.48 & 23.69 & 2.4 \\
\hline $\begin{array}{l}\text { Cement } \\
\text { slurry }\end{array}$ & 0.45 & 146.7 & 0.0010 & 1.03 & 20.50 & 2.1 \\
\hline
\end{tabular}




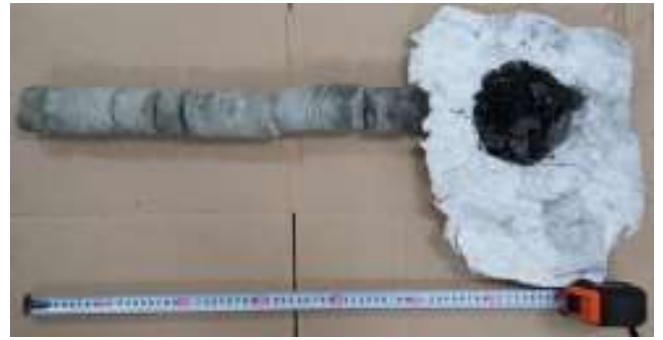

Fig. 3. Cement slurry penetration into unworked coal.

\section{CONCLUSION}

As per the results of the technology tests to increase yield load frame support by complete filling of behind-anchoring space with grout in mine conditions, the conclusions are formulated as follows:

1. Filling of behind-anchoring space with grout provides secure contact between steel frame support and containing rocks that helps to prevent rock displacement development and increase load on roof support.

2. There is penetration of cement slurry into coal mass, what also in turn provides high degree of adhesion of grout mix to unworked coal, and strengthens coal edge.

3. Reinforced canvas used as a formwork, provides 'squeezing out' of the exceed moisture, contributes to the concrete strength development.

4. Mine fire resistance is provided.

5. Working hours for skin grouting by means of reinforced canvas is significantly lower than construction of reinforced concrete tightening. Consumption of concrete tightening is comparable to consumption of dry shake at behind-anchoring space filling of $100 \mathrm{~mm}$ thickness. Delivery of reinforced tightening to the face and its laying is executed manually, and cement slurry is fed by a pump unit that significantly reduces working hours required for walling. Furthermore, resistance of grouting layer of $100 \mathrm{~mm}$ to external loads is comparable to the parameters of reinforced concrete tightening.

\section{REFERENCES}

[1] GOST R 51748-2001. Metal pliable frame supports. Arch Support. General specifications. - M., 2001.

[2] V. F. Demin, V. V. Yavorskiy, and T. V. Demina, "Study of the stress state of the near-contour mass around the excavation depending on the influence of mining and technological factors," International Journal of Applied and Fundamental Research, No. 7-2, pp. 196-200, 2015.

[3] V. Matten, I., Seeger, and H. Zillessen, "Filling of behind-anchoring space of the roads with natural anhydrite," Gluckauf, No. 14, 1980.

[4] F. Brayt and Yu. Krae, "Filling of interstices outside the frame of the drift lining by Bulflex method," Gluckauf, No. 13, 1980.

[5] V.P. Tatsienko, A.S. Liskovets, and M.V. Sablin, "Increase of the Capacity of the Frame Support by Full Filling of the BehindAnchoring Space With Backfill Material,” Bulletin KuzSTU, №2, pp. 45-52, 2018. DOI: 10.26730/1999-4125-2018-2-45-52

[6] Federal regulations and rules in the field of industrial safety "Manual on calculation and application of anchorage in coal mines". Moscow. ZAO STC PD. 2015

[7] Yu.V. Burkov, "Substantiation and development of technology of permanent mine workings on the basis of injecting the hardening of rocks," Abstr. Diss. ... doctor. tech. sciences', Kemerovo, 1998.

[8] V. Goleman, "Practical examples of the mechanized filling machine filling of the behind-anchoring space," Gluckauf, No 24, 1979.

[9] H. Irnberger, "Progress of technology filling in of the behindanchoring space in the workings," Gluckauf, No. 14, 1980.

[10] N.V. Gilyazidinova, N.Y. Rudkovskaya, and T.N. Santalova, "The research in the use of monolithic concrete for the mine construction," Bulletin KuzSTU, №1, pp. 31-35, 2017.

[11] M.V. Sokolov, S.M. Prostov, and A.V Pokatilov, "Geomechanical justification of parameters of injection fixing of the bulk ground basis of the complex of sloping,” Bulletin KuzSTU, №2, pp. 5-19, 2017.

[12] Martyanov V.L. Evaluation of the working out difficulty on quarry fields of Kuzbass coal deposits / V.L. Martyanov // Journal of Mining and Geotechnical Engineering. - 2018. - №1. - C. 35-41. DOI: 10.26730/2618-7434-2018-1-35-41

[13] Y.A. Masaev, V.Y. Masaev, and L.D. Filina, "New developments in the field of bolting and increase of stability of rock outcrops in mines,” Bulletin KuzSTU, №1, pp. 41-44, 2015.

[14] Markov S.O. Georadar research of the block structure for drilling and blasting operations on Zarechnyi open pit mine / S.O. Markov, M.A. Tyulenev, E.G. Kuzin // Journal of Mining and Geotechnical Engineering. - 2018. - №1. - C. 56-63. DOI: 10.26730/2618-74342018-1-56-63

[15] Ermakova I.A. Setting of flow parameters during release of ore in caving systems / I.A. Ermakova // Journal of Mining and Geotechnical Engineering. - 2018. - №1. - C. 4-10. DOI: 10.26730/2618-7434-2018-1-04-10 